\title{
Uusia puolustusaineita gerberasta
}

\author{
Miia Ainasoja, Ursula Malm, Anja Lampio, Satu Koskela ja Teemu Teeri
}

Gerberalaboratorio, Soveltavan biologian laitos, Latokartanonkaari 7, PL27, 00014 Helsingin yliopisto; teemu.teeri@helsinki.fi

\section{Tiivistelmä}

Kasvien syntetisoimien kemiallisten yhdisteiden (sekundäärimetaboliittien) kirjo on laaja ja suhteessa tähän monimuotoisuuteen vain muutamien yhdisteiden biokemiallinen synteesireitti tunnetaan. Leikko- ja ruukkukasvina kasvatettava sädelatva eli gerbera (Gerbera hybrida, Asteraceae) tuottaa maanpäällisiin osiinsa kahta glukosidista karvasainetta, gerberiiniä ja parasorbosidia. Jälkimmäinen tunnetaan myös pihlajan karvasaineena. Glukosidit sellaisenaan torjuvat hyönteistuhoilta, ja sieniperäisten taudinaiheuttajien läsnäollessa ne hajotetaan aglykoneiksi joilla on sienitauteja torjuva vaikutus. Olemme tutkineet gerberan sekundääriaineenvaihdunnan tuotteita ja niistä vastaavia geenejä, ja löytäneet avaingeenin, joka johtaa gerberiinin ja parasorbosidin biosynteesiin. Yhdisteet muodostuvat asetyyli-CoA:sta ja malonyyli-CoA:sta reaktiossa, jonka ensimmäistä vaihetta katalysoi kasveille tyypillinen polyketidisyntaasiperheeseen kuuluva entsyymi. Vastaavanlaisia yhdisteitä tunnetaan sienistä ja bakteereista, mutta aiemmin ei tiedetty niitä esiintyvän myös kasveilla.

Uutettavan gerberiiniaglykonin määrä eri gerberalajikkeissa korreloi harmaahomeen (Botrytis cinerea) kestävyyden kanssa. Gerberiini/parasorbosidireitin aktiivisuus toimii siten merkkiominaisuutena taudinkestävyydelle ja mahdollistaa kestävyystestauksen ilman taudinaiheuttajaa. Tutkimuksemme yhtenä tavoitteena on selvittää miten tämä merkkiominaisuus on helpoin mitata lajiketestauksessa. Vaihtoehdot ovat metaboliittien kemiallinen analyysi, lähetti-RNA:n analyysi tai DNA-testi.

Tutkimuksemme laajempana tavoitteena on osoittaa gerberasta löydetyn gerberiini/parasorbosidireitin hyödynnettävyys pelto- ja puutarhakasvien kestävyysjalostuksessa. Mikäli reitti saadaan koottua toimivaksi uudessa kohdekasvissa, on odotettavissa että se toimii hyvin laajasti lähtömetaboliittien ollessa perusaineenvaihdunnan välituotteita.

Esitetyllä metabolisella kestävyysjalostuksella on todennäköisesti laaja sovellettavuusala, joka viime kädessä riippuu kunkin hyötykasvin tautien ja tuholaisten herkkyydestä k.o. aineille. Ensimmäinen sovellusala olisi puutarhassa ja kasvihuoneella viljeltävät koristekasvit. Soveltaminen elintarvikkeiden raaka-aineisiin edellyttää toksikologisia tutkimuksia, mutta lähtökohtana on merkillepantavaa, että parasorbosidia esiintyy luonnostaan pihlajanmarjoissa, marja-aroniassa ja amerikkaisessa karpalossa.

\section{Asiasanat}

Sädelatva, gerbera, asterikasvit, harmaahome, sekudääriaineenvaihdunta, polyketidisyntaasi, geeninsiirto, GM-jalostus 


\section{Johdanto}

Kasvinsuojelun perinteisiin keinoihin kuuluu pelto- ja puutarhakasvien jalostaminen kasvitauteja ja tuhohyönteisiä kestäviksi. Perinteinen jalostustyö on pitkäjänteistä ja aikaa vievää, mutta sillä saadaan edelleen erinomaisia tuloksia uusien kestävien lajikkeiden muodossa. Kestävyysjalostus on luonteeltaan jatkuvaa ja riippuvaista kunkin viljelykasvilajin geneettisestä monimuotoisuudesta.

Taudin- ja tuholaiskestävyyden suora mittaaminen viljelykasveilla on ongelmallista monista syistä. Kestävyyden mittaaminen vaatii erikoisolosuhteet esim. kasvihuoneissa, ja tuotantokasvihuoneiden läheisyydessä taudinaiheuttajien ja tuholaisten laajamittainen käsittely ei useinkaan tule kysymykseen. Erityisesti nopeakiertoisilla koristekasveilla, joiden lajikkeet saattavat vaihtua jopa vuosittain, nopea laboratoriopohjainen menetelmä uusien lajikkeiden arvioimiseksi olisi arvokas. Paitsi viljelijöiden kannalta, myös jalostajan kannalta taudin- ja tuholaiskestävyyden kytkeminen helposti mitattaviin parametreihin olisi erittäin hyödyllinen apuväline.

Perinteisen kestävyysjalostuksen rinnalle on viime aikoina kehittynyt geeninsiirtotekniikoihin perustuva GM-jalostus. Tunnetuin esimerkki on Bt-toksiinin tuotto viljelykasvissa, jolloin kasvi on (kohdennetusti) kestävä tuhohyönteisiä vastaan. Myös GM-jalostettuja viruksenkestäviä kasveja on viljelyssä, kun taas sieni- ja bakteeritauteja vastaan ei ole onnistuttu kehittämään samalla tavalla tehoavia GM-menetelmiä. GM-jalostusta on pääosin sovellettu Yhdysvalloissa ja erityisesti EU:n alueella tekniikkaan on suhtauduttu varauksella. Ilmapiiri on kuitenkin muuttumassa. GM-lupien käsittelyssä pidetyn pitkän tauon aikana on alan riskien tutkimus edistynyt ja Eurooppalaiset tuntuvat olevan valmiita punnitsemaan uudelleen GM-menetelmien hyötyjä kasvinjalostuksessa.

Tähän mennessä GM-tekniikoilla suoritetun kestävyysjalostuksen johtolankana on ollut tuottaa kasvissa bakteeriperäisiä haittaproteiineja (Bt-toksiineja) tai käyttää jalostuksessa virusperäisiä geenejä. Tässä esitetyssä tutkimuksessa sovelletaan kasvien omien geenien käyttöä kestävyysjalostuksessa, jolloin yhdessä hyötykasvissa toimiva kestävyystekijä siirretään toiseen hyötykasviin. Vaikka jalostusmenetelmässä käytetään geenitekniikkaa, lopputuloksen kannalta uudet GM-lajikkeet muistuttavat enemmän perinteisillä (kauko)risteytyksillä aikaansaatuja lajikkeita, kuten Euroopassa laajalti viljeltyjä rukiin geenejä sisältäviä rehuvehnälajikkeita. Tämän tutkimuksen johtolankana on käyttää kasvien omia geenejä hyötykasvien kestävyysjalostuksessa.

\section{Gerberan karvasaineet}

Leikko- ja ruukkukasvina kasvatettava sädelatva eli gerbera tuottaa maanpäällisiin osiinsa kahta glukosidista karvasainetta, gerberiiniä ja parasorbosidia. Jälkimmäinen tunnetaan myös pihlajan karvasaineena. Glukosidit sellaisenaan torjuvat hyönteistuhoilta, ja sieniperäisten taudinaiheuttajien läsnäollessa ne hajotetaan aglykoneiksi joilla on sienitauteja torjuva vaikutus. Olemme tutkineet gerberan sekundääriaineenvaihdunnan tuotteita ja niistä vastaavia geenejä, ja löytäneet avaingeenin, joka johtaa gerberiinin ja parasorbosidin biosynteesiin.

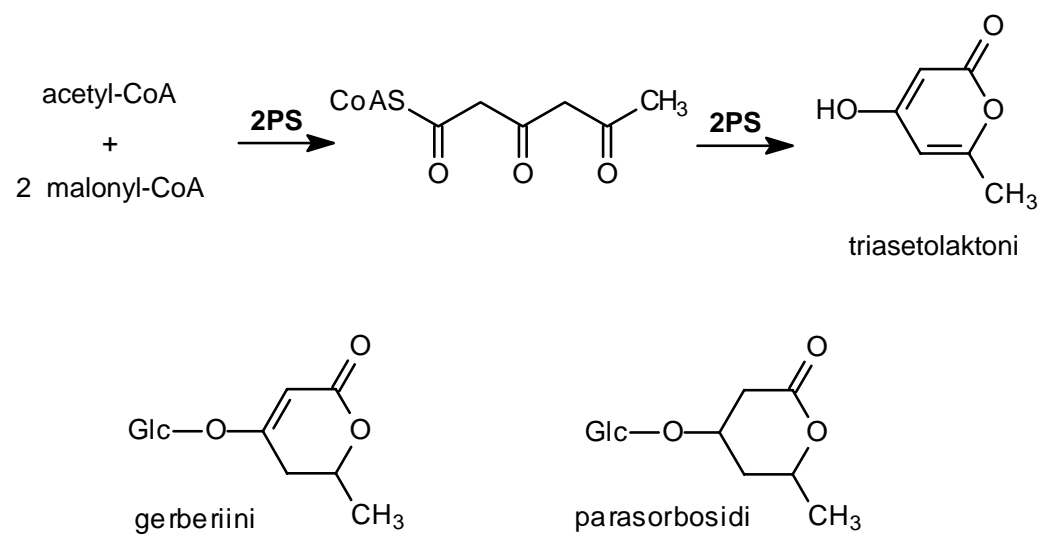

Kuva 1

Gerberiini ja parasorbosidi ovat gerberassa esiintyviä karvasaineita. 2-pyronisyntaasi (2PS) vastaa niiden esiasteen triasetolaktonin biosynteesistä. 2PS, 2-pyronisyntaasi; Glc, glukoosi. 
Olemme tutkineet gerberan sekundääriaineenvaihduntaan liittyvää geenitoimintaa kahden eri yhdisteryhmän suhteen. Kukinnon värityksen kannalta tärkeiden antosyaanien ja muiden flavonoidien biosynteesiin liittyvien geenien kautta olemme selvittäneet kukinnon anatomian suhteen säädellyn geenitoiminnan periaatteita (Helariutta ym. 1993, Kotilainen ym. 1994, Helariutta ym. 1995a, Elomaa ym. 1998, Elomaa ym. 2003. Flavonoidireitin avainentsyymiä kalkonisyntaasia (CHS) koodaavia geenejä eristäessämme löysimme gerberasta yhteensä kolme sukulaisgeeniä, joista vain kaksi koodasi CHS-entsyymiä. Kolmas osoittautui CHS:n tapaan polyketidisyntaasiksi, mutta katalysoi eri reaktiota ja sai sen mukaan nimekseen 2-pyronisyntaasi (2PS) (Helariutta ym. 1995b, Helariutta ym. 1996, Eckermann ym. 1998). 2PS entsyymiä muodostuu lähes kaikkiin gerberan maanpäällisiiiin solukkoihin (Kuva 1).

\section{Siirtogeenisistä gerberalinjoista karvasaineet puuttuvat}

Gerberan geenien toiminnallisessa tutkimuksessa siirtogeenitekniikat ovat avainasemassa. Geeninsiirron avulla tutkittava geeni voidaan sammuttaa ns. antisense-menetelmällä, jolloin voidaan tutkia kasveja, joilta kyseinen geeniaktiivisuus puuttuu. Antisense-tekniikalla tehdyissä siirtogeenisissä gerberalinjoissa 2PS entsyymiä ei muodostu lainkaan. Linjojen metaboliittianalyysien perusteella niistä puuttuvat erityisesti gerberassa runsaana esiintyvät glukosidiset laktonit gerberiini ja parasorbosidi, joiden esiaste triasetolaktoni muodostuu 2PS reaktiossa (Kuva 1). Gerberiinin ja parasorbosidin lisäksi kasveissa on kahden muun metaboliitin määrä dramaattisesti vähentynyt. Flavoneihin kuuluvaa apigeniiniä ja kumariineihin kuuluvaa 4-hydroksi-5-metyylikumariinia (HMC) ei muodostu juuri lainkaan (Koskela ym. 2005). On tarkemmin selvittämättä miksi myös nämä metaboliitit puuttuvat, mutta molemmat kuuluvat polyketidiryhmään gerberiinin ja parasorbosidin tapaan. Niin ikään polyketideihin kuuluvien antosyaanien määrä ei ole anti-2PS kasveissa vähentynyt (Eckermann ym. 1998).

Kirjallisuuden perusteella gerberiini ja parasorbosidi ovat karvasaineita, joilla on hyönteisherbivoriaa torjuvia ominaisuuksia (Pyysalo ja Kuusi 1971, Numata ym. 1990). Alustavat havainnot kasvihuoneella tukevat tätä käsitystä, anti-2PS linjat ovat helposti hyönteisten kiusaamia (Kuva 2). Kasvit ovat myös herkkiä harmaahomeelle laboratoriokokeittemme perusteella (Koskela ym. 2005). Kirjallisuuden sekä omien tutkimustemme mukaan yhdisteiden aglykonit ovat fungisidisia (Buston ja Roy 1949, Koskela ym. 2005).

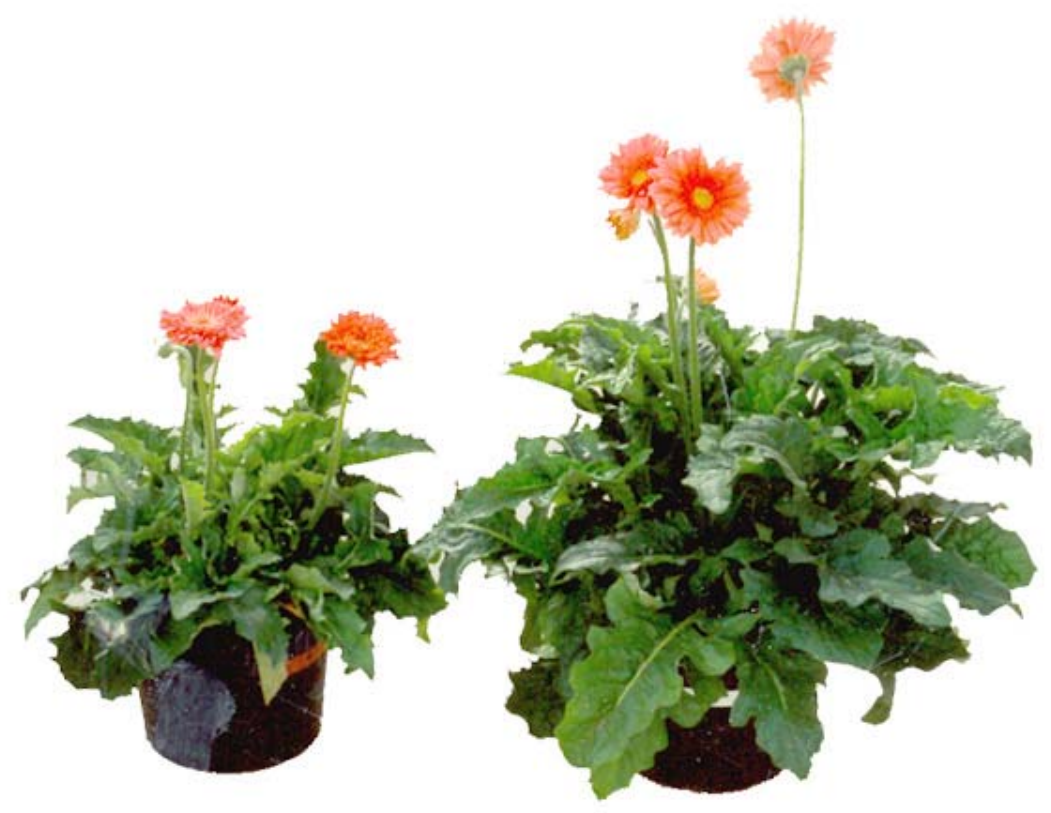

Kuva 2

Siirtogeenisen anti-2PS gerberalinjan (vasemmalla) kasvu kasvihuoneella on häiriintynyt ripsiäisvaurioiden takia verrattuna ei-siirtogeeniseen kontrolliin (oikealla). Anti2PS linjassa 2PS entsyymiä eikä metaboliitteja gerberiini, parasorbosidi, apigeniini ja HMC muodostu lainkaan. Tämä viittaa siihen, että k.o. yhdisteillä on merkitystä hyönteisherbivorian torjumisessa 


\title{
Gerberalajikkeiden harmaahomeenkesto korreloi gerberiinin kanssa
}

Siirtogeeniset kokeet viittaavat siihen, että gerberiini ja parasorbosidi, mahdollisesti myös apigeniini ja HMC, liittyvät kasvin puolustukseen mm. harmaahometta vastaan. Olemme määrittäneet parasorbosidia lukuun ottamatta näiden metaboliittien (aglykoniset) pitoisuudet neljässäkymmenessä kaupallisessa tai kehitteillä olevassa gerberalajikkeissa. Alustavien hometestausten perusteella gerberiiniaglykonin pitoisuus kasvissa korreloi harmaahomeenkeston kanssa (Kuva 3), joka voi antaa mahdollisuuden seuloa uusia lajikkeita niiden kemiallisen profiilin perusteella.

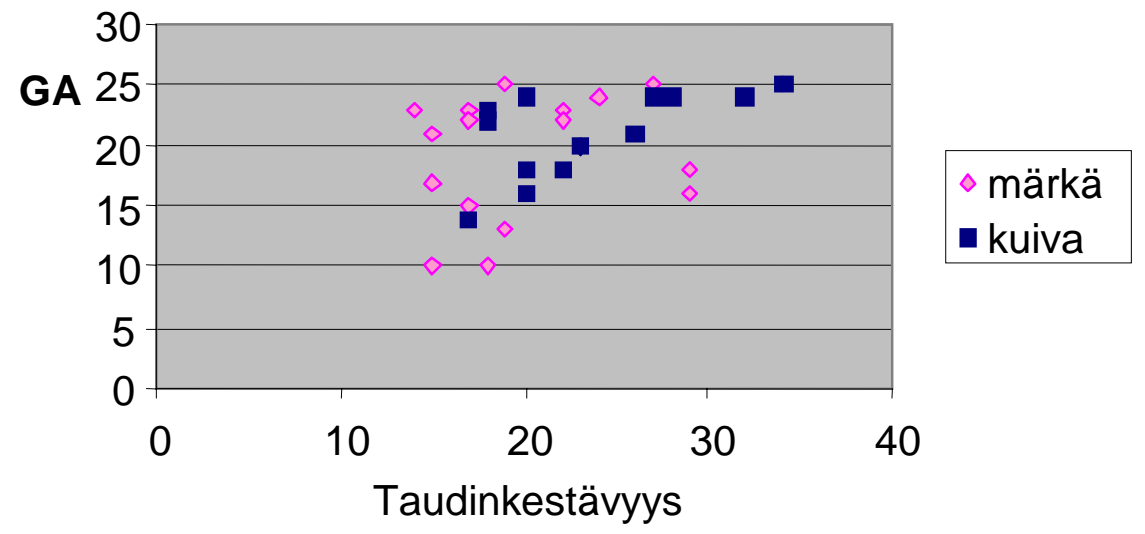

\begin{abstract}
Kuva 3
Harmaahomeinfektion etenemisen ja kukintojen gerberiiniaglykonin (GA) määrän välinen riippuvuus (molemmat asteikot kvalitatiivisia luokka-asteikkoja). Kun kokeesta hylätään sumutuksen kastelemat kukinnot ('märät'), saadaan selvä riippuvuus missä muutama lajike muodostaa poikkeuksen.
\end{abstract}

\section{Viljelykasvien metaboliamuokkaus}

Siirtogeenisillä gerberalinjoilla tehdyt kokeet osoittavat, että gerberiini ja parasorbosidi sekä niiden aglykonit ovat tärkeä osa gerberan puolustusmekanismia. 2-pyronisyntaasin lisäksi metaboliareitin muita entsyymejä ei vielä tunneta, mutta niiden selvitessä gerberiini/paraorbosidireittiä voitaneen hyödyntää pelto- ja puutarhakasvien kestävyysjalostuksessa yleisemminkin GM-jalostusta soveltaen. 2-pyronisyntaasi käyttää substraattinaan perusaineenvaihdunnan yhdisteitä (asetyyli-CoA ja malonyyli-CoA), joten metaboliareitti saadaan todennäköisesti toimimaan missä tahansa kasvissa.

Gerberiiniin ja parasorbosidiin liittyvällä metabolisella kestävyysjalostuksella on todennäköisesti laaja sovellettavuusala, joka viime kädessä kuitenkin riippuu kunkin hyötykasvin tautien ja tuholaisten herkkyydestä k.o. aineille. Ensimmäinen sovellusala olisi puutarhassa ja kasvihuoneella viljeltävät koristekasvit. Soveltaminen elintarvikkeiden raaka-aineisiin edellyttää toksikologisia tutkimuksia, mutta lähtökohtana on merkillepantavaa, että parasorbosidia esiintyy luonnostaan pihlajanmarjoissa, marja-aroniassa ja amerikkaisessa karpalossa.

\section{Kirjallisuusluettelo}

Buston, H.W. \& Roy, S.K. 1949. The physiological activity of some simple unsaturated lactones. I. Effect on the growth of certain microorganisms. Arch. Biochem. 22: 1-7.

Eckermann, S., Schröder, G., Schmidt, J., Strack, D., Edrada, R.A., Helariutta, Y., Elomaa, P., Kotilainen, M., Kilpeläinen, I., Proksch, P., Teeri, T.H. \& Schröder, J. 1998. New pathway to polyketides in plants. Nature 396: 387-390. 
Elomaa, P., Mehto, M., Kotilainen, M., Helariutta, Y., Nevalainen, L. \& Teeri, T.H. 1998. A bHLH transcription factor mediates organ-, region- and flower type specific signals on dihydroflavonol-4-reductase ( $d f r$ ) gene expression in the inflorescence of Gerbera hybrida (Asteraceae). Plant J. 16: 93-99.

Elomaa, P., Uimari, A., Mehto, M., Albert, V.A., Laitinen, R.A.E. \& Teeri, T.H. 2003. Activation of anthocyanin biosynthesis in Gerbera hybrida (Asteraceae) suggests conserved protein-protein and protein-promoter interactions between the anciently diverged monocots and eudicots. Plant Phys. 133: 1831-1842.

Helariutta, Y., Elomaa, P., Kotilainen, M., Seppänen, P. \& Teeri, T.H. 1993. Cloning of cDNA coding for dihydroflavonol 4 reductase (DFR) and characterization of dfr expression in the corollas of Gerbera hybrida var. Regina (Compositae). Plant Mol. Biol. 22: 183193.

Helariutta, Y., Kotilainen, M., Elomaa, P. \& Teeri, T.H. 1995a. Gerbera hybrida (Asteraceae) imposes regulation at several anatomical levels during inflorescence development on the gene for dihydroflavonol-4-reductase. Plant Mol. Biol. 28: 935-941.

Helariutta, Y., Elomaa, P., Kotilainen, M., Griesbach, R.J., Schröder, J. \& Teeri, T.H. 1995b. Chalcone synthase-like genes active during corolla development are differentially expressed and encode enzymes with different catalytic properties in Gerbera hybrida (Asteraceae). Plant Mol. Biol. 28: 47-60.

Helariutta, Y., Kotilainen, M., Elomaa, P., Kalkkinen, N., Bremer, K. Teeri, T,H, \& Albert, V. 1996. Duplication and functional divergence in the chalcone synthase gene family of Asteraceae: evolution with substrate change and catalytic simplification. Proc. Natl. Acad. Sci. U.S.A. 93: 9033-9038.

Koskela, S., Ainasoja, M., Söderholm, P., Wennberg, T., Klika, K.D., Ovcharenko, V.V., Kylänlahti, I., Harjunpää, T., Yli-Kauhaluoma, J., Pihlaja, K., Vuorela, P. \& Teeri, T.H. 2005. Polyketide derivatives active against Botrytis cinerea in Gerbera hybrida. Käsikirjoitus.

Kotilainen, M., Helariutta, Y., Elomaa, P., Paulin, L. \& Teeri, T.H. 1994. A corolla- and carpel-abundant, nonspecific lipid transfer protein gene is expressed in the epidermis and parenchyma of Gerbera hybrida var. Regina (Compositae). Plant Mol. Biol. 26: 971-978.

Numata, A., Takahashi, C., Fujiki, R., Kitano, E., Kitajima, A.\& Takemura, T. 1990. Plant constitutents biologically active to insects. VI. Antifeedants for larvae of the yellow butterfly Eurema hecabe mandarina in Osmunda japonica. Chem. Pharm. Bull. 28: 2862-2865.

Pyysalo, H. \& Kuusi, T. 1971. The taste in the berries of mountain ash. The glycosidic precursor of sorbic acid, Suomen kemistilehti: 393-396. 